EISSN: 2706 -7947 ISSN: 2077- 4613

DOI: $10.36632 /$ mejas/2021.11.3.53

Journal homepage: www.curresweb.com

Pages: 659-671

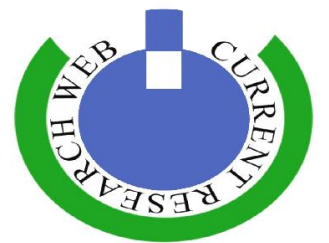

\title{
Geology, Petrology and Radioactivity of the Younger Granite and Associated Pegmatites along Wadi Umm Balad Area, North Eastern Desert, Egypt
}

\begin{abstract}
Ahmed Ali Abu Steet
Nuclear Materials Authority, P.O 530 Al Maadi, Cairo, Egypt

Received: 24 June 2021 Accepted: 10 August 2021 Published: 20 August 2021

ABSTRACT

The present study focuses on the younger granite and associated radioactive pegmatites of Wadi Umm Balad area that forming the northern parts of Gabal Gattar uranium province, North Eastern Desert of Egypt. The younger granite at this region is intruded into volcanosedimentary associations of Dokhan volcanics and Hammamat sedimentary rocks. It is dissected by numerous dike swarms as well as pegmatites, aplites and quartz veins and can be classified as monzogranite. It displays I-type characteristics, being ferroan, alkali-calcic and metaluminous originated in post-orogenic environment. The radioactive anomalies are recorded in pegmatites hosted within this granite. They have associations of radioactive minerals including zircon, columbite-(Fe), pyrochlore, xenotime and uranothorite. The distribution of trace elements in these pegmatites is higher than those in the host monzogranite, evident by the higher concentrations of $\mathrm{Zr}, \mathrm{Nb}, \mathrm{Y}$, Th and U. Like other showings in the Basement Complex of the Eastern Desert, the elevated concentrations of these elements could be explained as the result of differentiation from granites to pegmatites. The overall geochemical data confirmed that the studied pegmatites can be classified as Rare-Element, NYF-type systems.
\end{abstract}

Keywords: Monzogranite, I-type granite, Uranium,Thorium, Radioactive minerals.

\section{Introduction}

In Egypt, a majority of rare metal Precambrian pegmatites occur mostly in late-tectonic to anorogenic granitoid (younger granites), especially those outcropped in the North Eastern Desert (NED) (e.g. Nossiar, 1987; Mohamed et al., 1994; Ali 2007; Asran et al., 2013; Abu Steet et al., 2018; El Sundoly, 2021). However, other investigations have shown that they also occur on a minor scale intruded in the older metamorphic rocks in the South Eastern Desert (Saleh, 2007). These researches have presented the field relationships between the pegmatites and host rocks and their associated gamma-ray spectrometric data (radiometric signatures), which emphasizing the contents and distribution of $U$ and $T h$. The concerned pegmatites mostly show high concentrations of $U, T h, Z r, N b$ and $\mathrm{Ta}$, and mostly hosted in the younger granites.

Wadi Umm Balad area $\left(9.5 \mathrm{~km}^{2}\right)$ is located between latitudes $27^{\circ} 06^{\prime} 16^{\prime \prime}$ and $27^{\circ} 08^{\prime} 11^{\prime \prime} \mathrm{N}$ and longitudes $33^{\circ} 11^{\prime} 49^{\prime \prime}$ and $33^{\circ} 13^{\prime} 26^{\prime \prime} \mathrm{E}$ and is accessible by desert track from the Hurghada city (Fig. 1a). In this area, radioactive pegmatites were developed in the younger granite (YG), which intruded within the older Dokhan volcanics (DV) and Hammamat sedimentary rocks (HS). It forms part of the northern peripheries of Gabal Gattar that constitutes one of the prominent uranium provinces in the Eastern Desert of Egypt (Fig. 1b). This paper presents geological, petrological and radiometrical studies of the younger granite and associated pegmatites of Wadi Umm Balad area.

\section{Sampling and Methodology}

Sampling procedures involved collection of representative samples from the radioactive pegmatites and the host younger granite. Thin sections were prepared in order to determine the mineralogical compositions and textural relationships of the studied rocks. Six samples from the host granite and five samples from radioactive pegmatites were analysed by means of wet chemical

Corresponding Author: Ahmed Ali Abu Steet, Nuclear Materials Authority, P.O 530 Al Maadi, Cairo, Egypt. E-mail: abusteet63@gmail.com 
techniques for major oxides, whereas the trace elements were determined by X-ray fluorescence (Phillips PW 1410 together with a MO-target tube operated at $50 \mathrm{kv}$ and $30 \mathrm{~m} \mathrm{~A}$ ). Heavy mineral separation was carried out for the radioactive pegmatite samples. Representative mineral grains were analyzed using an Environmental Scanning Electron Microscope (ESEM) model Philips XL 30, attached with energy dispersive X-ray spectra (EDX) microanalyzer at an operating voltage of $25 \mathrm{KV}$, 1-2mm diameter, 60-120 second counting time and high resolution backscattered electron images (BSE). All the previously mentioned analyses were done at the laboratories of Nuclear Materials Authority of Egypt.

\section{Geological Setting and Petrography}

The basement complex of Wadi Umm Balad area consists mainly of an island arc complex (Fig. 1c); DV that represent the oldest rock unit (620-580 Ma old; Stern, 1981; Ressetar and Monrad, 1983; Abdel-Rahman and Doig, 1987) and HS of molasse-type (585 $\pm 13 \mathrm{Ma}$; Wilde and Youssef, 2002). The DV and HS interfinger in volcanosedimentary successions that accumulated in Ediacaran extensional basins. These rocks are intruded by younger pink granite with sharp contacts (610-550 Ma; Hassan and Hashad, 1990; Stern and Gottfried, 1986; Beyth et al., 1994). The study area occurs in the peripheral parts along the intersection of Wadi Umm Balad and Wadi El Atrash, whereas it is characterized by low to moderate mountains.

The DV in the study area are forming the southwestern extension of Gabal El Dokhan (Fig. 1b). They comprise andesites, dacites, as well as their associated pyroclastics, especially ignimbrites (Abu Steet 2002). Generally, they are of moderate relief (Fig. 2a), very fine grain size and grey to greyish pink in colour. The HS in the mapped area are exposed as relatively low hills and masses. They are represented by alternated beds of greywackes and siltstones, striking NE-SW with variable dips to the northwest. The HS show light grey, greenish grey, deep green and black colours.

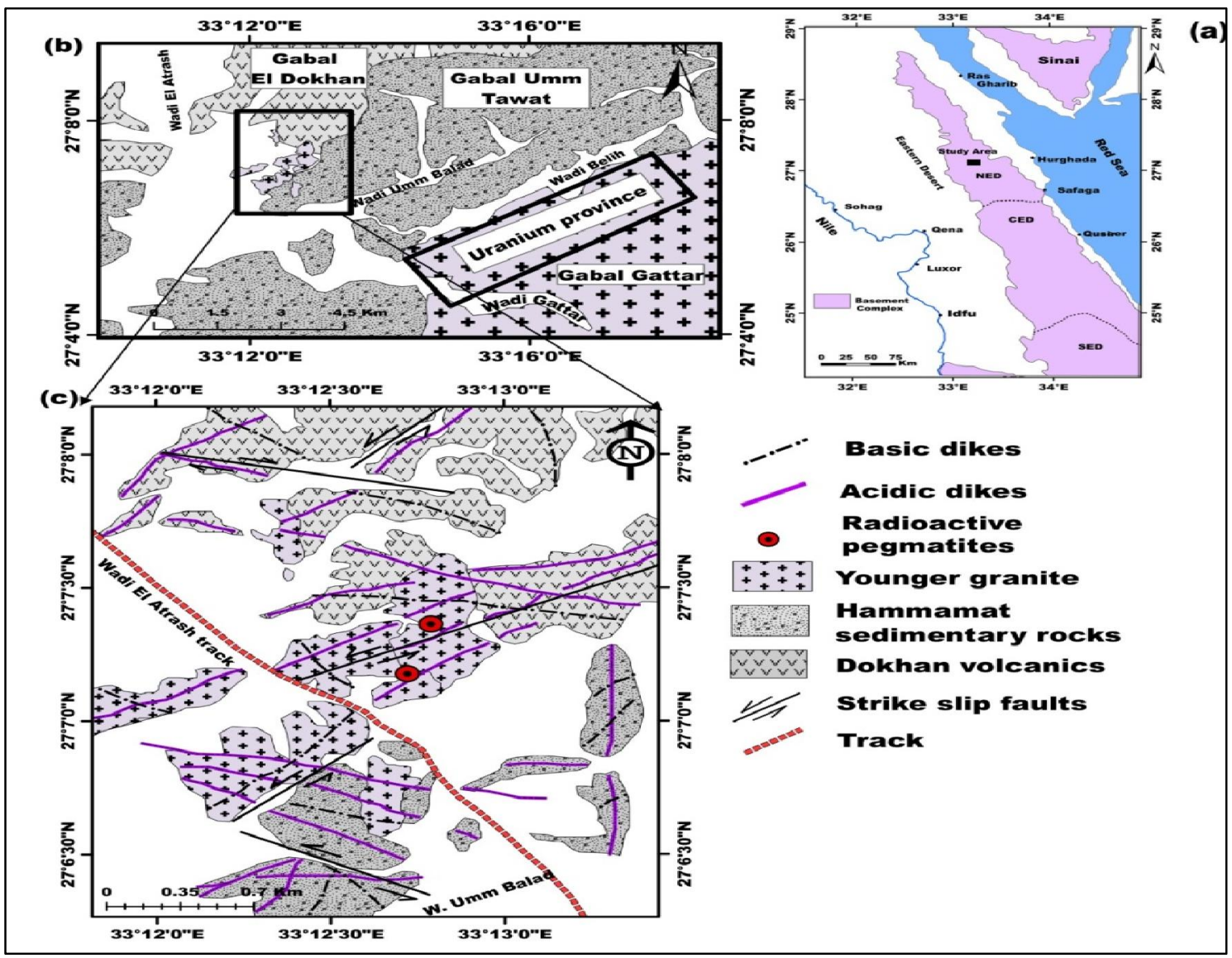

Fig. 1: (a) Location map of Wadi Umm Balad area, (b) Geological map of Gabal Gattar uranium province showing projection of the study area, and (c) Geological map of Wadi Umm Balad area, NED, Egypt. 
The YG is exposed as scattered outcrops of low to moderate topography. It is medium to coarsegrained and greyish pink in colour. It intrudes both DV and HS with sharp intrusive contacts; in some parts it sends offshoots into them (Figs. 2b and c). A few xenoliths of HS and DV are recorded enclosed in the YG. These xenoliths are of variable size (from $2 \mathrm{~cm}$ up to $10 \mathrm{~cm}$ ) with subrounded and elongated shape (Fig. 2d). The YG is highly jointed and shows slight alterations, especially along fault planes. It is highly weathered, showing exfoliation, bouldery and cavernous weathering. It is dissected by felsic and mafic dikes striking dominantly to the NE-SW and NNW-SSE directions, which ranging in thickness from 0.5 to $3 \mathrm{~m}$. It is invaded by numerous quartz veins, aplites and pegmatites. The pegmatites occur as lenticular and irregular bodies through the YG. They always occur at the marginal parts of the YG as well as along fracture and fault zones or at the contacts with the older rocks. They have variable dimensions range from about $0.5 \mathrm{~m}$ to $1.5 \mathrm{~m}$ wide and from $2 \mathrm{~m}$ to about $5 \mathrm{~m}$ long. Some radioactive pegmatites were recorded and their locations were projected on the geological map (Fig. 1c).
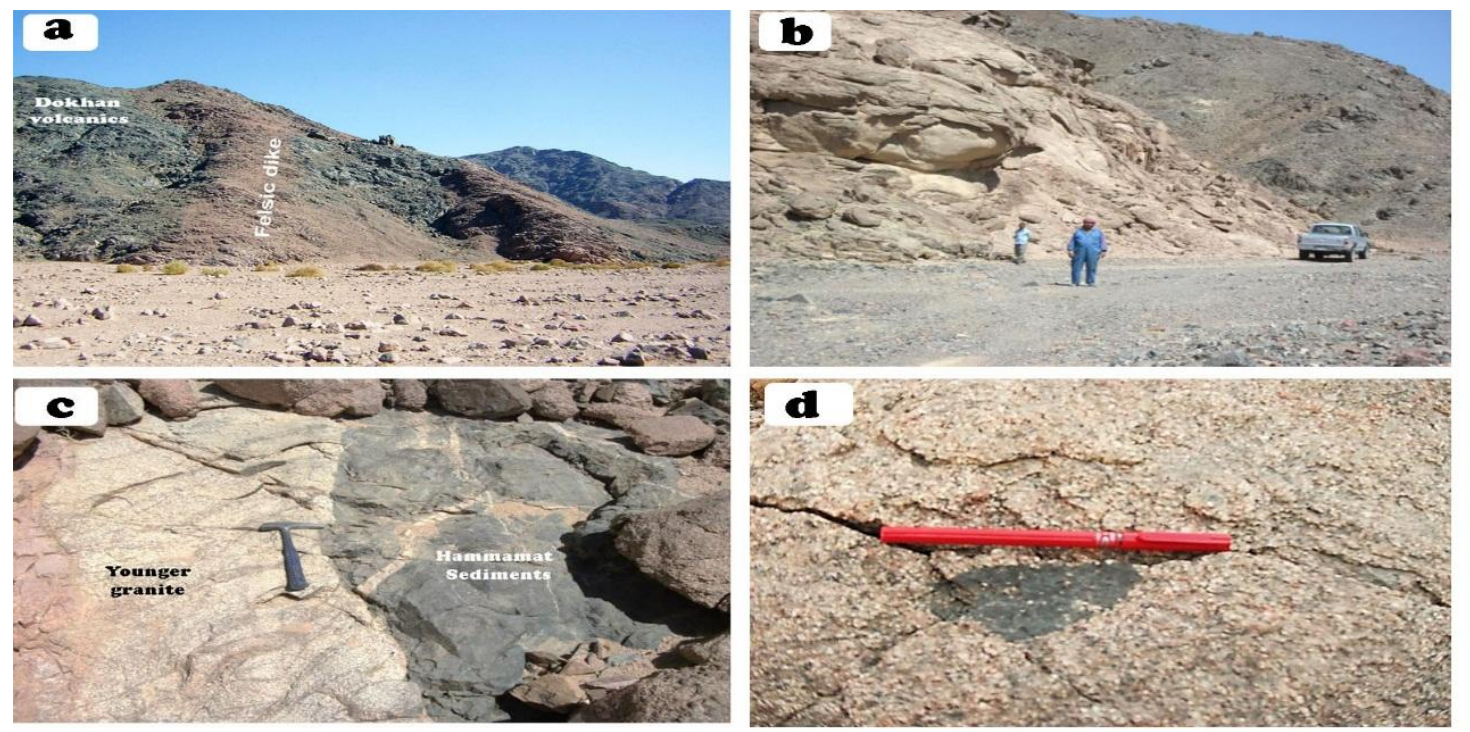

Fig. 2: (a) Felsic dike cutting through DV of low to moderate topography, (b) Highly exfoliated YG intruding DV with sharp intrusive contact, (c) YG intruding HS with sharp contact and sending offshoots into them, and (d) Elongated xenolith of HS enclosed in YG of Wadi Umm Balad area, NED, Egypt.

The hand specimens of this granite are medium-to coarse-grained and greyish pink in colour. In the present work, six thin sections were chosen for modal analyses. The results were listed in Table (1). According to the modal classification (Streckeisen, 1976), the younger granite was plotted within the monzogranite field (Fig. 3).

Table 1: Modal composition of representative younger granite from Wadi Umm Balad area, NED, Egypt

\begin{tabular}{ccccccc}
$\begin{array}{c}\text { Sample } \\
\text { No. }\end{array}$ & \multicolumn{5}{c}{ Mineral composition (vol. \%) } \\
\cline { 2 - 7 } & $\begin{array}{c}\text { Quartz } \\
(\mathbf{Q})\end{array}$ & $\begin{array}{c}\text { K-feldspar } \\
(\mathbf{A})\end{array}$ & $\begin{array}{c}\text { Plagioclase } \\
\mathbf{( P )}\end{array}$ & Mica & Hornblende & $\begin{array}{c}\text { Accessories } \\
\text { and opaques }\end{array}$ \\
\hline $\mathbf{1}$ & 31.33 & 29.62 & 24.54 & 7.42 & 3.25 & 3.84 \\
$\mathbf{2}$ & 30.32 & 29.81 & 23.18 & 8.36 & 3.17 & 5.16 \\
$\mathbf{3}$ & 31.12 & 30.18 & 25.25 & 7.41 & 2.54 & 3.50 \\
$\mathbf{4}$ & 28.83 & 31.15 & 27.74 & 7.22 & 2.06 & 3.00 \\
$\mathbf{5}$ & 33.98 & 28.34 & 21.15 & 8.87 & 3.26 & 4.40 \\
$\mathbf{6}$ & 28.15 & 29.55 & 26.58 & 7.85 & 3.75 & 4.12 \\
\hline
\end{tabular}




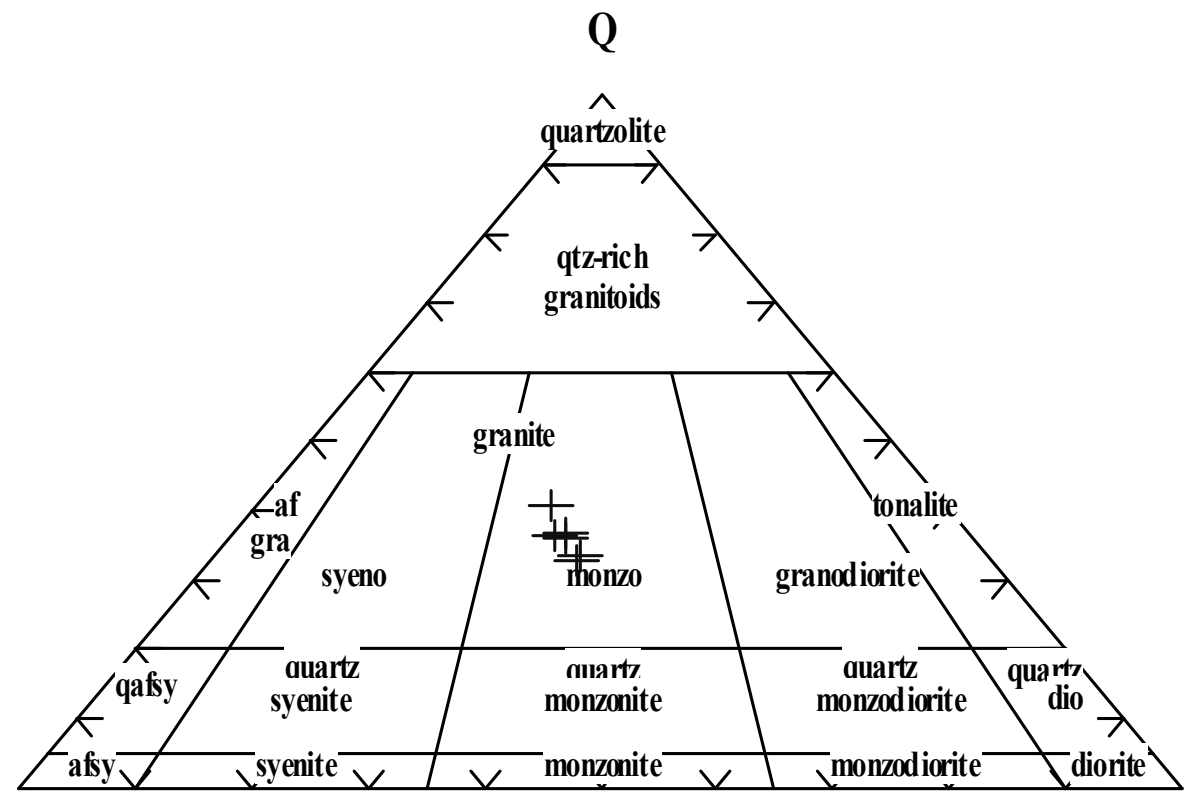

A

Fig. 3: Modal classification of the studied granite of Wadi Umm Balad area. Fields and nomenclature after Streckeisen (1976).

Microscopically, the granite commonly displays granular hybidiomorphic texture; mainly porphyritic. It is composed of K-feldspar with subequal amounts of plagioclase in addition to quartz. Biotite and/or hornblende are the main mafics. Sphene, apatite and zircon are commonly representing the accessory minerals whereas chlorite, epidote and iron oxides are secondary ones.

Plagioclase is of oligoclase composition. It occurs as anhedral to subhedral tabular crystals. The majority of plagioclase crystals show lamellar twinning indicated late crystallization phase. Commonly, the plagioclase is zoned; normally, the core being much more saussuritzed than the peripheries as they are of more calcic composition (Fig.4a).

$\mathrm{K}$-feldspar is present as either orthoclase or microcline perthite; the latter is less common. It displays several exsolution types including rod, patchy, flame and net perthites. Generally, they are cracked; the cracks are usually empty and sometimes filled with quartz and clay minerals. The perthite crystals enclose biotite and hornblende crystals, which are usually altered to chlorite and epidote. In some cases, the contact between the perthite crystals shows reaction rims mostly filled with quartz and/or minute crystals of albite (Fig. 4b).

Quartz is normally present as anhedral crystals. Quartz crystals commonly exhibit undulose extinction and cracking, indicating that they were subjected to high stresses. Inclusions of zircon, biotite, some small plagioclase and perthite are commonly found within the large quartz crystals.

Biotite forms euhedral, subhedral and anhedral flakes, of variable sizes. It is partially altered to chlorite and epidote (Fig. 4c). Euhedral titanite, small prisms of apatite and zircon are common inclusions within the biotite. Hornblende is less abundant in this granite. It occurs as anhedral to subhedral crystals (Fig. 4d). It is partially altered to epidote and chlorite.

The most abundant accessory minerals of this granite are apatite, titanite, opaques, and zircon. These minerals mostly appear as inclusions in the large crystals of the major phases (Figs.4e,f). Iron oxides, epidote, saussurite, sericite and chlorite are the common secondary minerals due to the alteration of the major constituents especially plagioclase, K-feldspar, biotite and hornblende. 

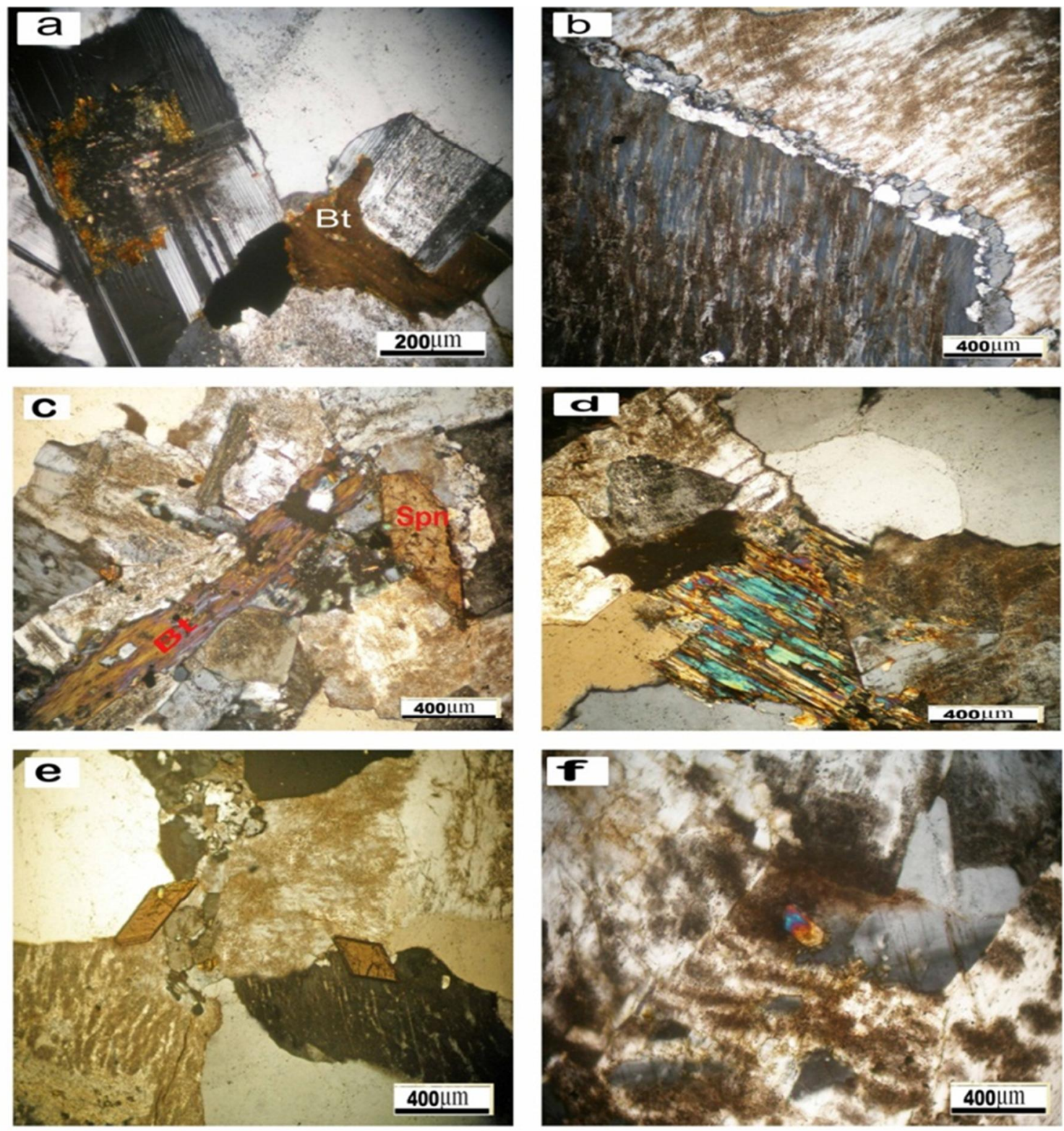

Fig. 4: (a) Saussuritized plagioclase at its inner zone associates biotite (Bt), C.N., (b) Reaction rims between two perthite crystals filled with quartz, C.N., (c) chloritized biotite associates titanite (spn), C.N. (d) Epidotized hornblende interstitial between perthite and quartz, C.N.,(e) well-formed crystals of titanite, C.N., and (f) zircon enclosed in perthite, C.N., at the studied YG of Wadi Umm Balad area, NED, Egypt.

\section{Geochemistry of Monzogranite}

Major oxides and trace elements analyses together with some chemical parameters of the investigated granite were listed in Table (2). The studied granite can be classified using the cationic classification $\mathrm{R}_{1}-\mathrm{R}_{2}$ of De la Roche et al., (1980), all samples plot in the monzogranite field (Fig. 5).

The studied monzogranite exhibits restricted range of relatively high $\mathrm{SiO}_{2}(68.82-70.20 \mathrm{wt} . \%)$ and total alkalis (av. $=8.47$ wt.\%). It has low abundances of $\mathrm{Fe}_{2} \mathrm{O}_{3} \mathrm{t}(\mathrm{av} .=3.70 \mathrm{wt} . \%), \mathrm{MnO}(\mathrm{av} .=0.12$ wt.\%), $\mathrm{MgO}$ (av. $=70$ wt.\%), $\mathrm{CaO}$ (av.=1.75 wt.\%), $\mathrm{TiO}_{2}\left(\mathrm{av} .=0.45\right.$ wt.\%) and $\mathrm{P}_{2} \mathrm{O}_{5}$ (av. 0.14\%) (Table 2). The differentiation index (DI) ranges from 91.8 to 93.2 , implying a highly differentiated granite affinity (Table 2). By using the binary relation between $\mathrm{K}_{2} \mathrm{O}$ and $\mathrm{Na}_{2} \mathrm{O}$ to discriminate between I- and S-type granites by Hine et al., (1978), the studied samples plot mainly in the I-type granite field (Fig. 6). On the $\mathrm{SiO}_{2}$ versus $\mathrm{A} / \mathrm{CNK}$ discrimination diagram of Chappell and White (1974), the analyzed samples are I-type granite and metaluminous to slightly peraluminous of Shand (1951) (Fig. 7). Based on the classification of Frost et al., (2001), most of the studied samples are ferroan (Fig. 8a), and they plot entirely in the alkali-calcic field (Fig. 8b). 
Table 2: Major oxides (wt. \%) and trace elements (ppm) analyses with some parameters and ratios of the studied granite, Wadi Umm Balad area, NED, Egypt.

\begin{tabular}{|c|c|c|c|c|c|c|c|}
\hline \multirow[b]{2}{*}{ Sample No } & \multicolumn{6}{|c|}{ Monzogranite } & \multirow[b]{2}{*}{ average } \\
\hline & M-1 & M-2 & M-3 & M-4 & M-5 & M-6 & \\
\hline \multicolumn{8}{|c|}{ Major oxides (Wt. \%) } \\
\hline $\mathrm{SiO}_{2}$ & 69.61 & 69.19 & 68.82 & 69.75 & 68.95 & 70.20 & 69.42 \\
\hline $\mathrm{TiO}_{2}$ & 0.45 & 0.42 & 0.46 & 0.42 & 0.57 & 0.39 & 0.45 \\
\hline $\mathrm{Al}_{2} \mathrm{O}_{3}$ & 14.18 & 14.41 & 14.35 & 14.15 & 14.52 & 14.24 & 14.31 \\
\hline $\mathrm{Fe}_{2} \mathrm{O}_{3}$ & 2.12 & 2.14 & 2.63 & 2.56 & 2.25 & 1.87 & 2.26 \\
\hline FeO & 1.48 & 1.1 & 1.74 & 1.17 & 1.21 & 1.05 & 1.29 \\
\hline MnO & 0.09 & 0.32 & 0.09 & 0.06 & 0.09 & 0.08 & 0.12 \\
\hline MgO & 0.74 & 0.78 & 0.7 & 0.65 & 0.69 & 0.61 & 0.70 \\
\hline $\mathrm{CaO}$ & 1.74 & 1.69 & 1.77 & 1.64 & 1.82 & 1.85 & 1.75 \\
\hline $\mathrm{Na}_{2} \mathrm{O}$ & 4.26 & 4.31 & 4.27 & 4.19 & 4.35 & 4.12 & 4.25 \\
\hline $\mathbf{K}_{2} \mathbf{O}$ & 4.32 & 4.25 & 3.92 & 4.32 & 4.13 & 4.37 & 4.22 \\
\hline $\mathrm{P}_{2} \mathrm{O}_{5}$ & 0.12 & 0.24 & 0.11 & 0.12 & 0.13 & 0.12 & 0.14 \\
\hline L.O.I & 0.86 & 1.17 & 1.13 & 0.92 & 0.92 & 0.85 & \\
\hline D. I & 92.1 & 92.5 & 91.8 & 92.7 & 92.4 & 93.2 & \\
\hline \multicolumn{8}{|c|}{ Trace elements (ppm) } \\
\hline $\mathbf{B a}$ & 838 & 957 & 915 & 918 & 835 & 915 & 896 \\
\hline $\mathbf{R b}$ & 82 & 95 & 108 & 148 & 108 & 135 & 113 \\
\hline $\mathrm{Sr}$ & 275 & 365 & 298 & 281 & 284 & 289 & 299 \\
\hline $\mathbf{G a}$ & 19.3 & 20.2 & 19.5 & 18.9 & 21 & 19.6 & 19.8 \\
\hline $\mathbf{T a}$ & 1.04 & 1.14 & 1.22 & 1.10 & 1.54 & 1.02 & 1.18 \\
\hline $\mathbf{N b}$ & 15.5 & 19.5 & 16.9 & 15.7 & 19 & 14.6 & 18.03 \\
\hline $\mathbf{Z r}$ & 268 & 295 & 282 & 359 & 335 & 252 & 298 \\
\hline $\mathbf{Y}$ & 23 & 26 & 24 & 23 & 25 & 21 & 24 \\
\hline Th & 9.95 & 9.6 & 11.18 & 11.6 & 10.85 & 11.7 & 10.81 \\
\hline $\mathbf{U}$ & 4.46 & 3.88 & 4.50 & 5.40 & 4.30 & 4.10 & 4.43 \\
\hline Th/U & 2.23 & 2.47 & 2.48 & 2.15 & 2.52 & 2.85 & 2.45 \\
\hline
\end{tabular}

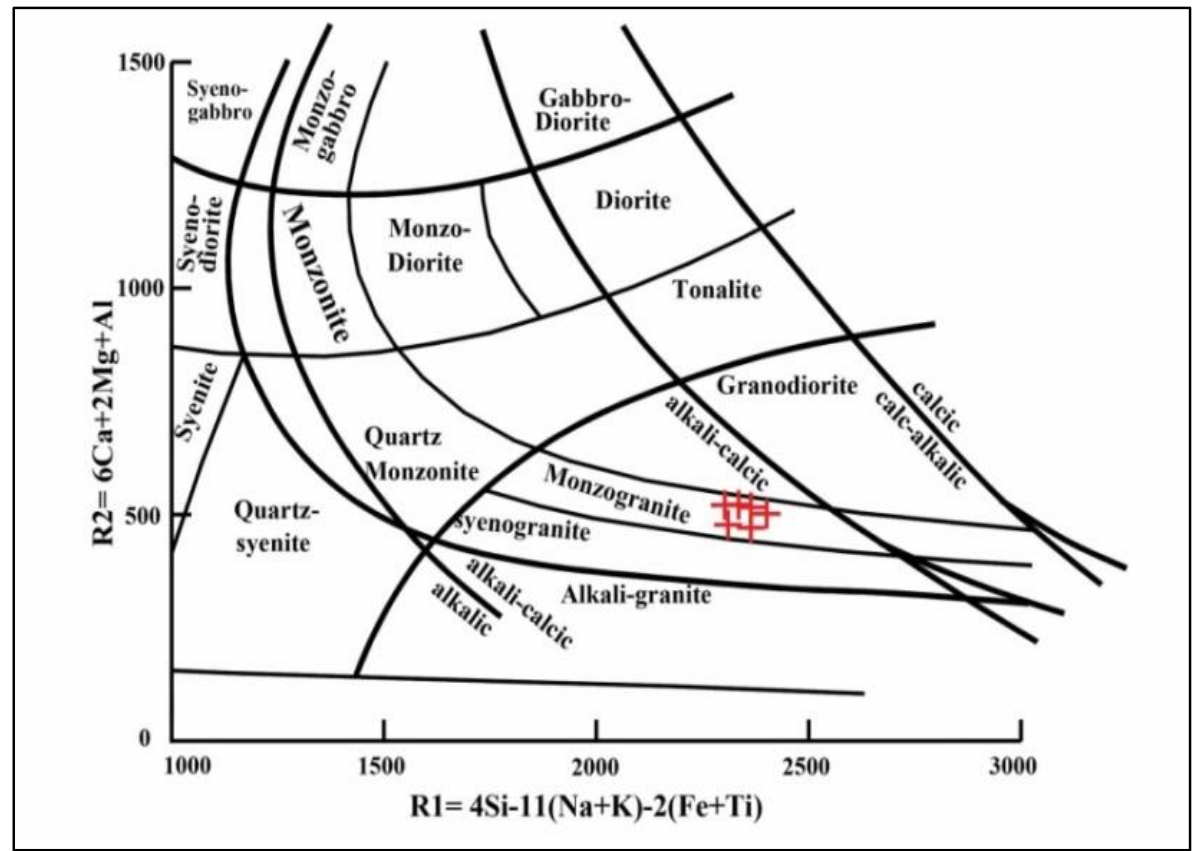

Fig. 5: Chemical classification diagram R1-R2 of De La Roche et al., (1980), for the studied granite, Wadi Umm Balad area, NED, Egypt. 


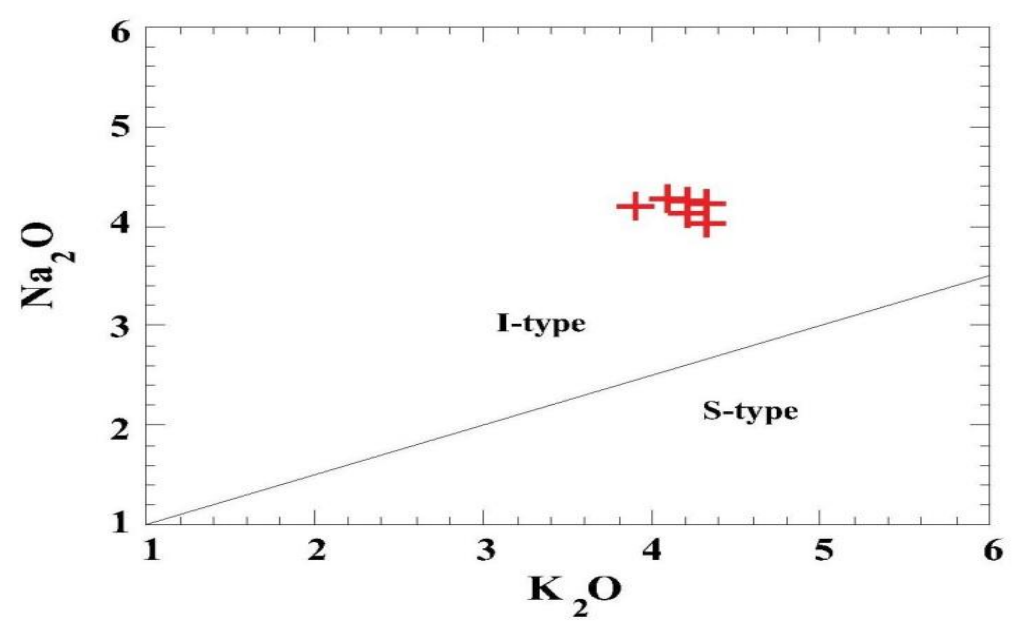

Fig. 6: $\mathrm{Na}_{2} \mathrm{O}$ versus $\mathrm{K}_{2} \mathrm{O}$ discrimination diagram between I- and S-type (Hine et al., 1978), for the studied granite, Wadi Umm Balad area, NED, Egypt.

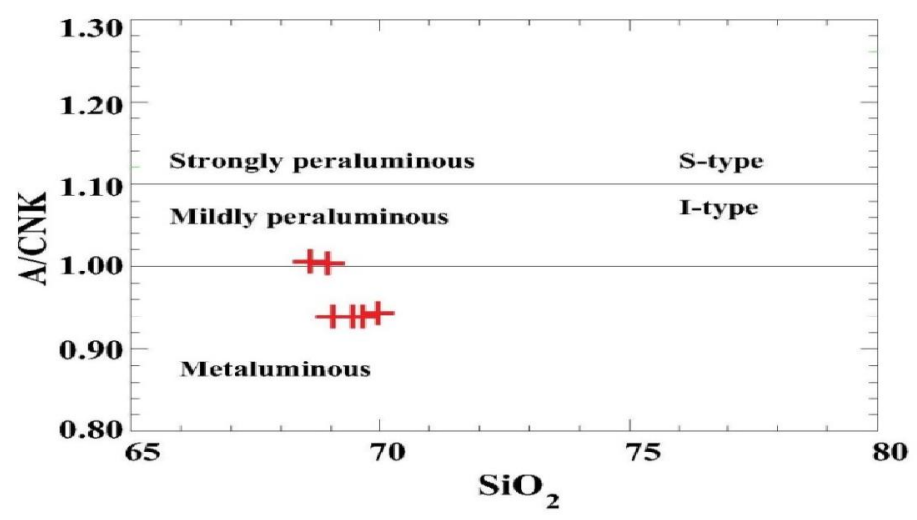

Fig. 7: $\mathrm{SiO}_{2}$ versus $\mathrm{A} / \mathrm{CNK}$ discrimination diagram. Divisions between highly peraluminous, mildly peraluminous and metaluminous after Shand (1951), and between I- and S-type after Chappell and White (1974), for the studied granite, Wadi Umm Balad area, NED, Egypt.

(a)

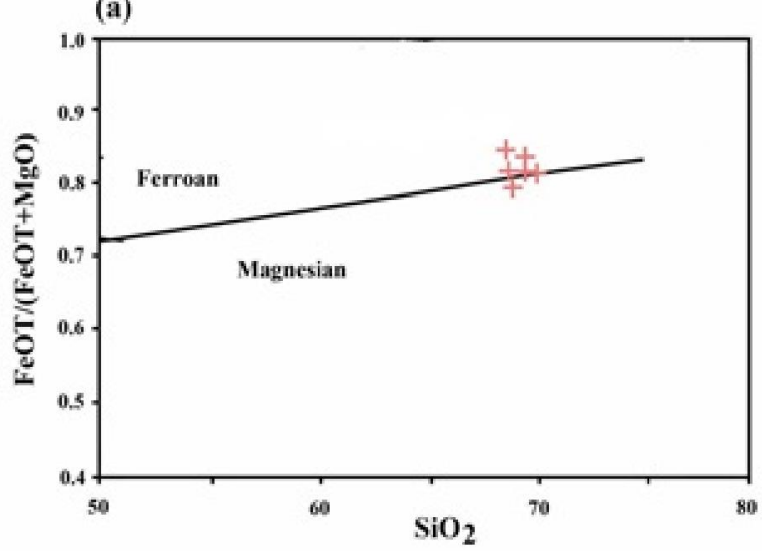

(b)

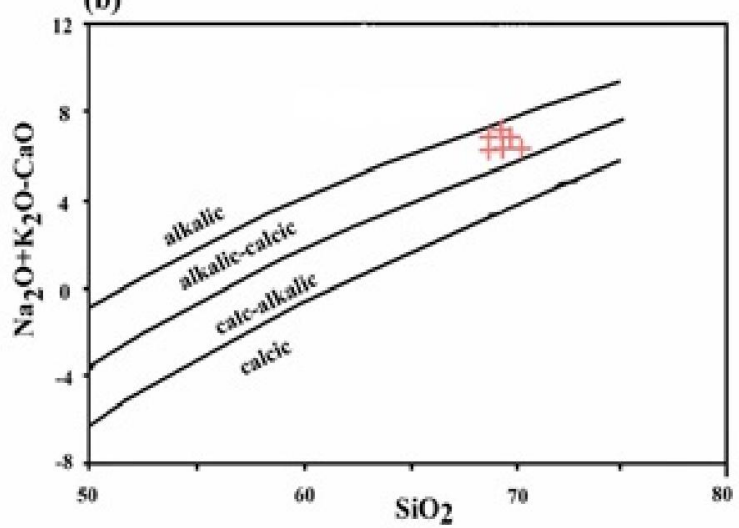

Fig. 8: (a) $\mathrm{SiO}_{2}$ versus $\mathrm{FeOt} /(\mathrm{FeOt}+\mathrm{MgO})$ and (b) $\mathrm{SiO}_{2}$ versus $\mathrm{Na}_{2} \mathrm{O}+\mathrm{K}_{2} \mathrm{O}-\mathrm{CaO}$ discrimination diagrams (Frost et al., 2001), for the studied granite, Wadi Umm Balad area, NED, Egypt.

Maniar and Piccoli (1989) categorized the settings where granitoid rocks were formed, on the basis of modal analyses and major element chemistry data, into six tectonic environments. To discriminate between the post-orogenic granites (POG) and continental arc granites (CAG) or continental collision granites (CCG) on the basis of molar A/CNK-A/NK ratios, the concerned granite falls within the post-orogenic granitoids field (POG) (Fig. 9). Also, the studied granite plots in the field 
of the post-collisional tectonic setting delineated by Pearce (1996) on $\mathrm{Rb}$ versus $(\mathrm{Y}+\mathrm{Nb})$ discrimination diagram (Fig. 10).

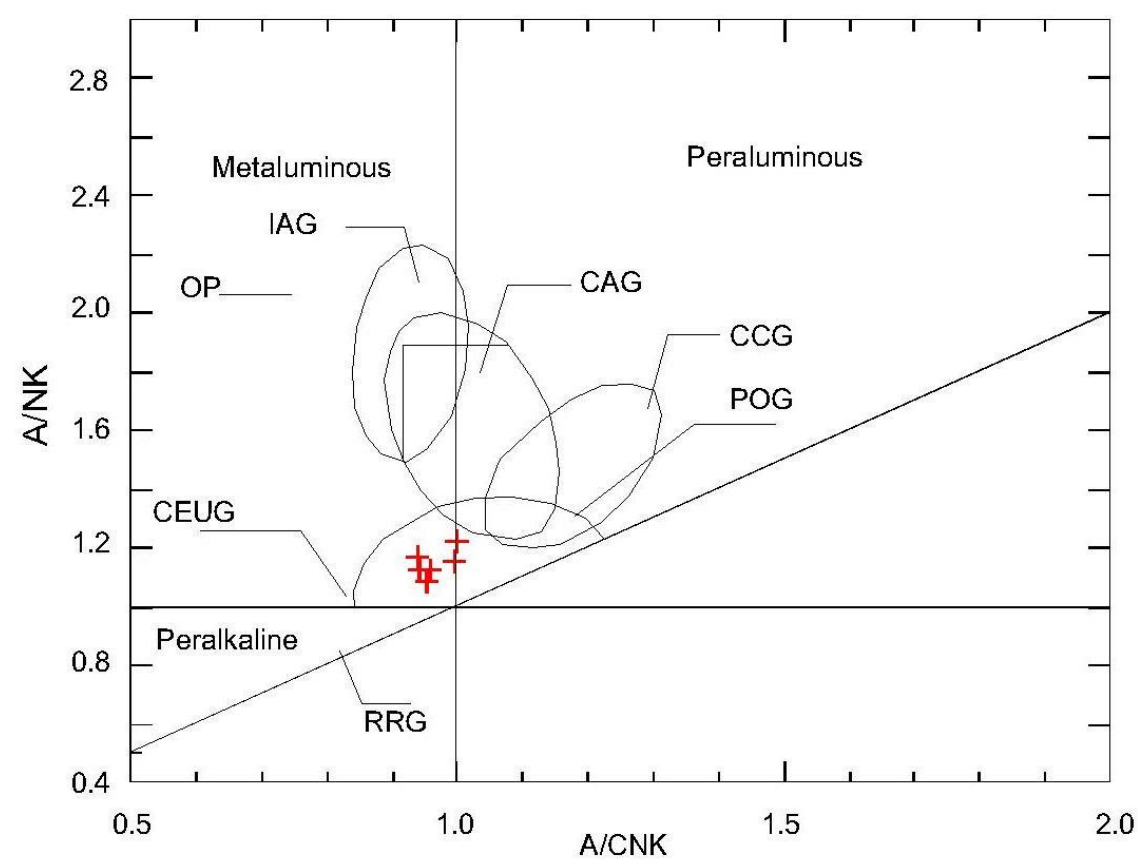

Fig. 9: A/CNK versus A/NK tectonic discrimination diagram (Maniar and Piccoli, 1989), for the studied granite, Wadi Umm Balad area, NED, Egypt.

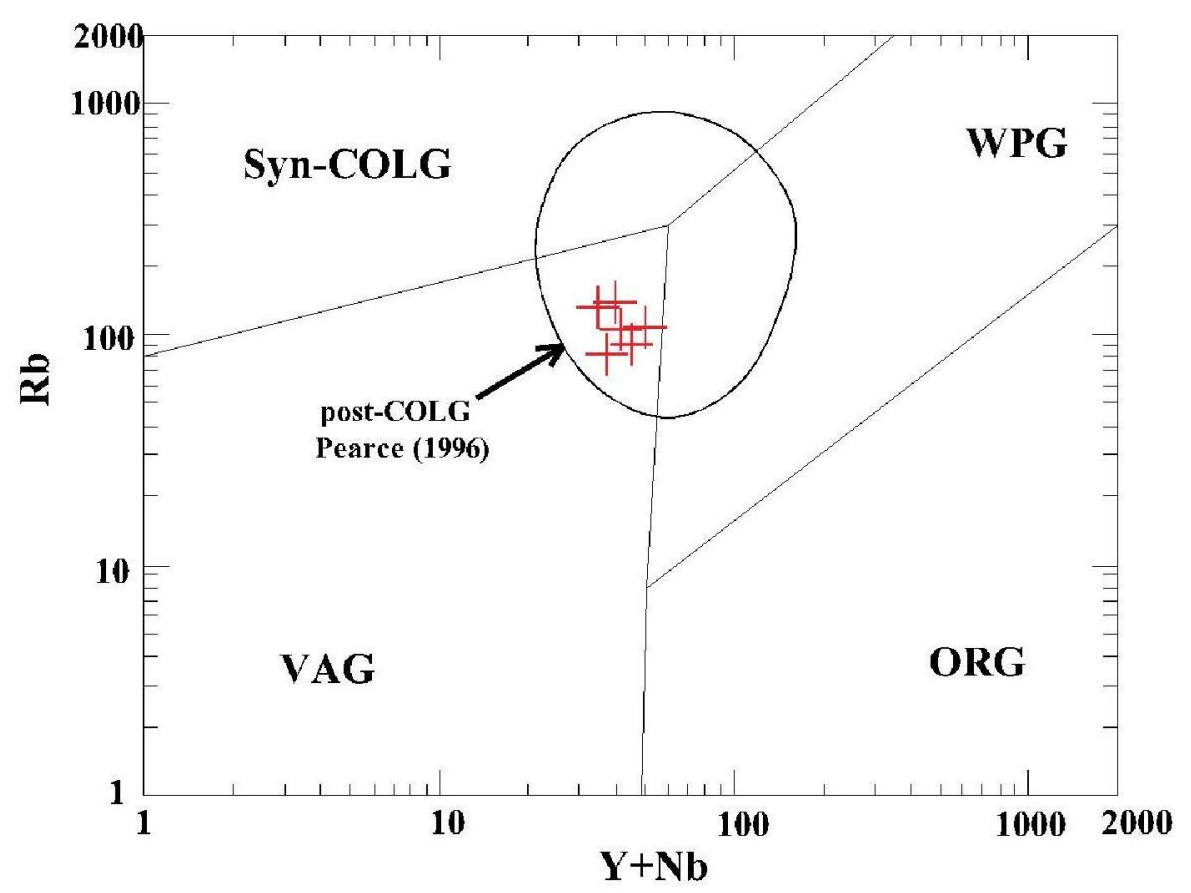

Fig. 10: $\mathrm{Rb}$ vs. $(\mathrm{Y}+\mathrm{Nb})$ tectonic discrimination diagram (Pearce et al., (1984) with post-collisional field after Pearce (1996), for the studied granite, Wadi Umm Balad area, NED, Egypt. WPG: Within Plate Granitoids, COLG: Collision Granitoids, ORG: Orogenic Related Granitoids and VAG: Volcanic Arc Granitoids. 


\section{Radioactivity and Mineralogy}

Ground radiometric survey for the study area was performed using a hand held scintillometer (model RS-230). This instrument measures eU (ppm), eTh (ppm), K (\%) and total gamma activity (cps). The background value of the total gamma intensities in the monzogranite $(180 \mathrm{cps})$ is relatively higher than those in the DV (120 cps) and HS (130 cps), which increase towards the highly differentiated rocks. Such granite displays post-magmatic alterations along faults and shear zones.

Radioactive pegmatites were registered in the monzogranite, showing different degrees of enrichment in $\mathrm{U}$ and $\mathrm{Th}$. Generally, they are forming a complete gradation from granitic to highly evolved pegmatitic facies. Most of the pegmatites are well-zoned with quartz core and K-feldspar in the outer zone (Fig. 11). They are generally white to pale pink, massive to locally foliated and coarsegrained. High gamma-ray intensities, up to $3000 \mathrm{cps}$ were recorded within the K-feldspar zones of these pegmatites.

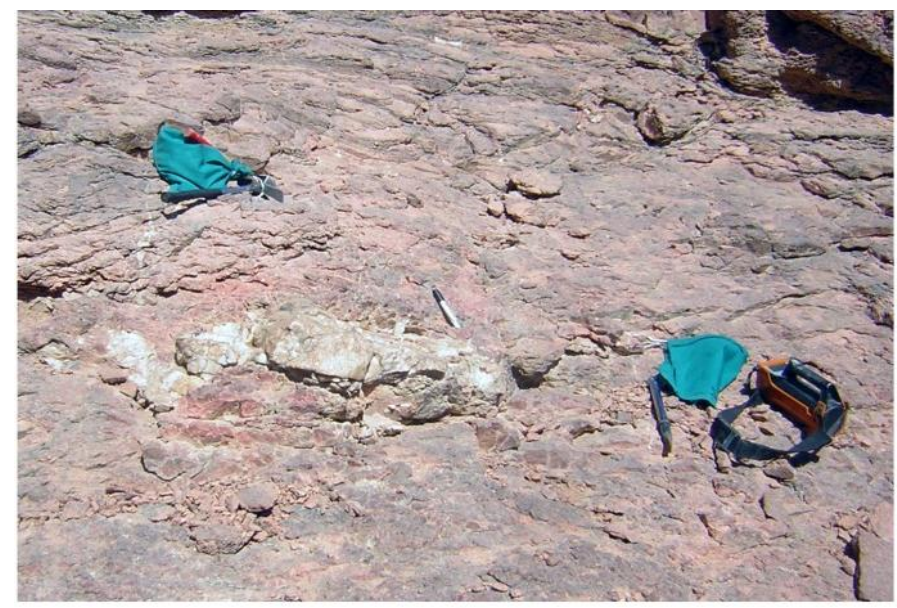

Fig.11: Zoned radioactive pegmatitic pocket, Wadi Umm Balad area, NED, Egypt.

Five radioactive pegmatitic samples were analysed for trace elements, the data were listed in Table (3). They have high concentrations in the elements $\mathrm{Nb}(\mathrm{av} .=615 \mathrm{ppm}), \mathrm{Ta}(\mathrm{av} .=39 \mathrm{ppm}), \mathrm{Zr}$ $(\mathrm{av} .=918 \mathrm{ppm}), \mathrm{Y}(\mathrm{av} .=602 \mathrm{ppm})$ besides $\mathrm{U}$ and Th. In order to determine the behavior and distribution of $\mathrm{U}$ and $\mathrm{Th}$ in the studied monzogranite and associated radioactive pegmatites, the calculated parameters (range, mean and eU/U ratios) for the chemical and radiometrical measurements are shown in Table (4).

The $\mathrm{U}$ contents along the monzogranite have average 4.43ppm, matching with that in typical granite (3.2 ppm, Flanagan 1976). On the other hand, Th displays marked higher concentrations (av. $=10.81 \mathrm{ppm}$ ). Mean $\mathrm{Th} / \mathrm{U}$ ratios is 2.45 , near that reported in the literature (3.0) for granitic rocks (Faüre, 1986). Although the monzogranite underwent post-magmatic alterations along the sheared parts, there are no evidences for $U$ mobilization and $U$ could be magmatically originated. The radioactive pegmatite samples are enriched in $\mathrm{Th}(\mathrm{av} .=693 \mathrm{ppm})$ and $\mathrm{U}(\mathrm{av} .=229 \mathrm{ppm})$ whereas mean $\mathrm{Th} / \mathrm{U}$ ratios $(\mathrm{av} .=3.0)$, relatively remains constant compared to the host monzogranite $(2.45)$.

Table 3: Selective trace elements contents of the radioactive pegmatite samples, Wadi Umm Balad area, NED, Egypt.

\begin{tabular}{ccccccc}
\hline Elements & $\mathbf{P - 1}$ & $\mathbf{P - 2}$ & $\mathbf{P - 3}$ & $\mathbf{P - 4}$ & $\mathbf{P - 5}$ & Average \\
\hline $\mathbf{T a}$ & 32 & 54 & 45 & 28 & 36 & 39 \\
$\mathbf{N b}$ & 534 & 846 & 663 & 430 & 601 & 615 \\
$\mathbf{Z r}$ & 825 & 1024 & 1245 & 629 & 866 & 918 \\
$\mathbf{Y}$ & 650 & 734 & 326 & 610 & 690 & 602 \\
$\mathbf{T h}$ & 532 & 846 & 963 & 458 & 667 & 693 \\
$\mathbf{U}$ & 223 & 257 & 271 & 149 & 243 & 229 \\
$\mathbf{T h} / \mathbf{U}$ & 2.4 & 3.3 & 3.6 & 3.1 & 2.7 & 3.0 \\
\hline
\end{tabular}


Table 4: Range, mean $(\overline{\mathrm{X}})$ and eU/U ratios of the chemical and radiometrical measurements of $U$ and Th in the studied granite and associated radioactive pegmatites of Wadi Umm Balad area, NED, Egypt.

\begin{tabular}{|c|c|c|c|c|c|c|c|c|c|}
\hline \multirow{3}{*}{ Rock type } & \multicolumn{4}{|c|}{$\begin{array}{c}\text { Chemical analyses } \\
\begin{array}{c}\mathrm{N}=6 \text { for monzogranite and } 5 \text { for } \\
\text { radioactive pegmatites) }\end{array} \\
\end{array}$} & \multicolumn{4}{|c|}{$\begin{array}{c}\text { Radiometric measurements } \\
\text { ( } \mathrm{N}=10 \text { for monzogranite and } 10 \text { for } \\
\text { radioactive pegmatites) }\end{array}$} & \multirow{3}{*}{$\mathrm{eU} / \mathbf{U}$} \\
\hline & \multicolumn{2}{|c|}{$\mathbf{U}$} & \multicolumn{2}{|c|}{ Th } & \multicolumn{2}{|c|}{$\mathbf{e U}$} & \multicolumn{2}{|c|}{ eTh } & \\
\hline & $\begin{array}{l}\text { Range } \\
\text { (ppm) }\end{array}$ & $\begin{array}{c}\overline{\mathbf{X}} \\
(\mathbf{p p m})\end{array}$ & $\begin{array}{l}\text { Range } \\
\text { (ppm) }\end{array}$ & $\begin{array}{c}\overline{\mathbf{X}} \\
(\mathbf{p p m})\end{array}$ & $\begin{array}{l}\text { Range } \\
\text { (ppm) }\end{array}$ & $\begin{array}{c}\overline{\mathbf{X}} \\
(\mathbf{p p m})\end{array}$ & $\begin{array}{l}\text { Range } \\
\text { (ppm) }\end{array}$ & $\begin{array}{c}\overline{\mathbf{X}} \\
(\mathbf{p p m})\end{array}$ & \\
\hline Monzogranite & $3.88-5.40$ & 4.43 & $9.60-11.7$ & 10.81 & $3.4-5.2$ & 4.3 & $10.2-12.3$ & 11.0 & 0.97 \\
\hline $\begin{array}{l}\text { Radioactive } \\
\text { pegmatites }\end{array}$ & $149-257$ & 229 & $458-963$ & 693 & $130-248$ & 218 & $470-1100$ & 705 & 0.95 \\
\hline
\end{tabular}

Dardier (2006) stated that, ratios of eU/U greater than one indicate recent $\mathrm{U}$ loss (while daughter products from the radioactive decay of $\mathrm{U}$ remain), on the other hand, if the eU/U ratios less than one indicate recent $U$ addition (the daughters which emit gamma-ray are not produced yet or at least the decay series does not reach the equilibrium state). In the present study, the monzogranite shows mean value of $\mathrm{eU} / \mathrm{U}$ ratios of 0.97 , while the radioactive pegmatites has mean value of $\mathrm{eU} / \mathrm{U}$ ratios of 0.95 (Table 3) suggesting limited uranium mobilization.

The relationships between $\mathrm{U}$, Th and other trace elements along the monzogranite towards the pegmatites are illustrated in Figures (12a-d). Uranium and Th show strong positive correlation $(\mathrm{r}=0.98)$ among the studied samples. Nearly, similar linear trends are shown between U-Nb, U-Zr and U-Y, indicating uranium enrichment due to magmatic processes. All these plots suggest that the enrichments of these elements are the result of differentiation from granite to highly evolved pegmatites. Briqueu et al., (1984) mentioned that $\mathrm{U}, \mathrm{Th}, \mathrm{Nb}, \mathrm{Y}$ and $\mathrm{Zr}$ behave incompatibly in granitic melt, so that where uranium concentration is controlled by magmatic processes, these elements would be expected to increase.
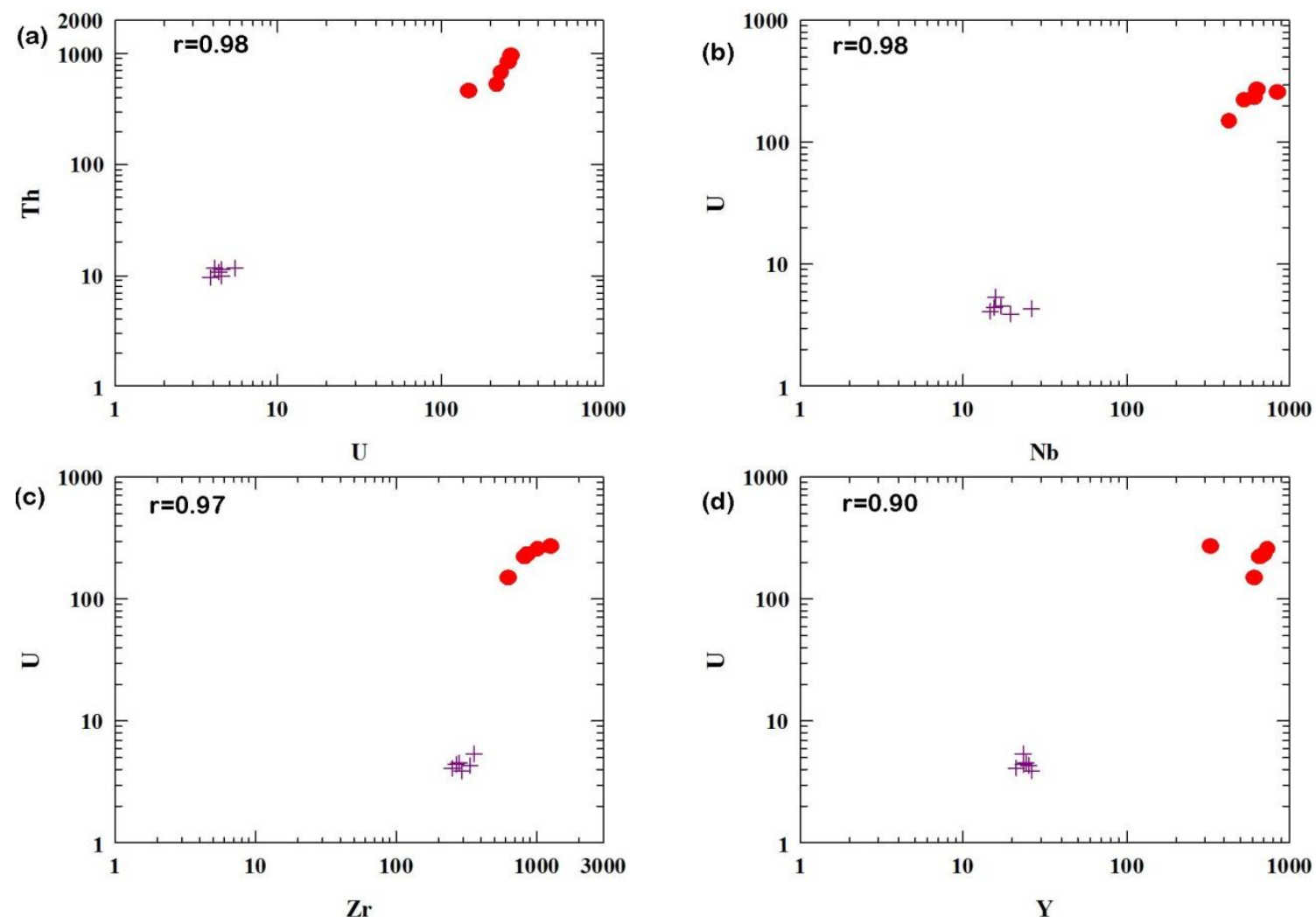

Fig. 12: Log-log variation diagrams (a) U-Th, (b) Nb-U, (c) Zr-U and (d) Y-U along the studied monzogranite and associated radioactive pegmatites, Wadi Umm Balad area, NED, Egypt. +: monzogranite, $\bullet$ : radioactive pegmatites, 
Mineralogical investigation of the collected radioactive samples is performed using heavy liquid separation and picking. The separated minerals were analyzed using Environmental Scanning Electron Microscope (ESEM). The obtained analysis clarified the presence of the radio-elements (U and Th) in the structure of these minerals. The most important radioactive minerals are: zircon $\left(\mathrm{Zr} \mathrm{SiO}_{4}\right)$, columbite $\left(\mathrm{Nb}_{2} \mathrm{O}_{6}\right)$, pyrochlore $\left[(\mathrm{U}, \mathrm{Fe}, \mathrm{Y}, \mathrm{Ca})(\mathrm{Nb}, \mathrm{Ta}) \mathrm{O}_{4}\right]$, xenotime $\left(\mathrm{YPO}_{4}\right)$ and uranothorite $\left[(\mathrm{Th}, \mathrm{U}) \mathrm{SiO}_{4}\right](\mathrm{Figs}$. 13a-f). The contents of $\mathrm{U}, \mathrm{Th}, \mathrm{Nb}, \mathrm{Zr}$ and $\mathrm{Y}$ in the radioactive pegmatites are much higher than those of monzogranite, indicating that uranium enrichment has occurred in the crystal lattice of these radioactive minerals.
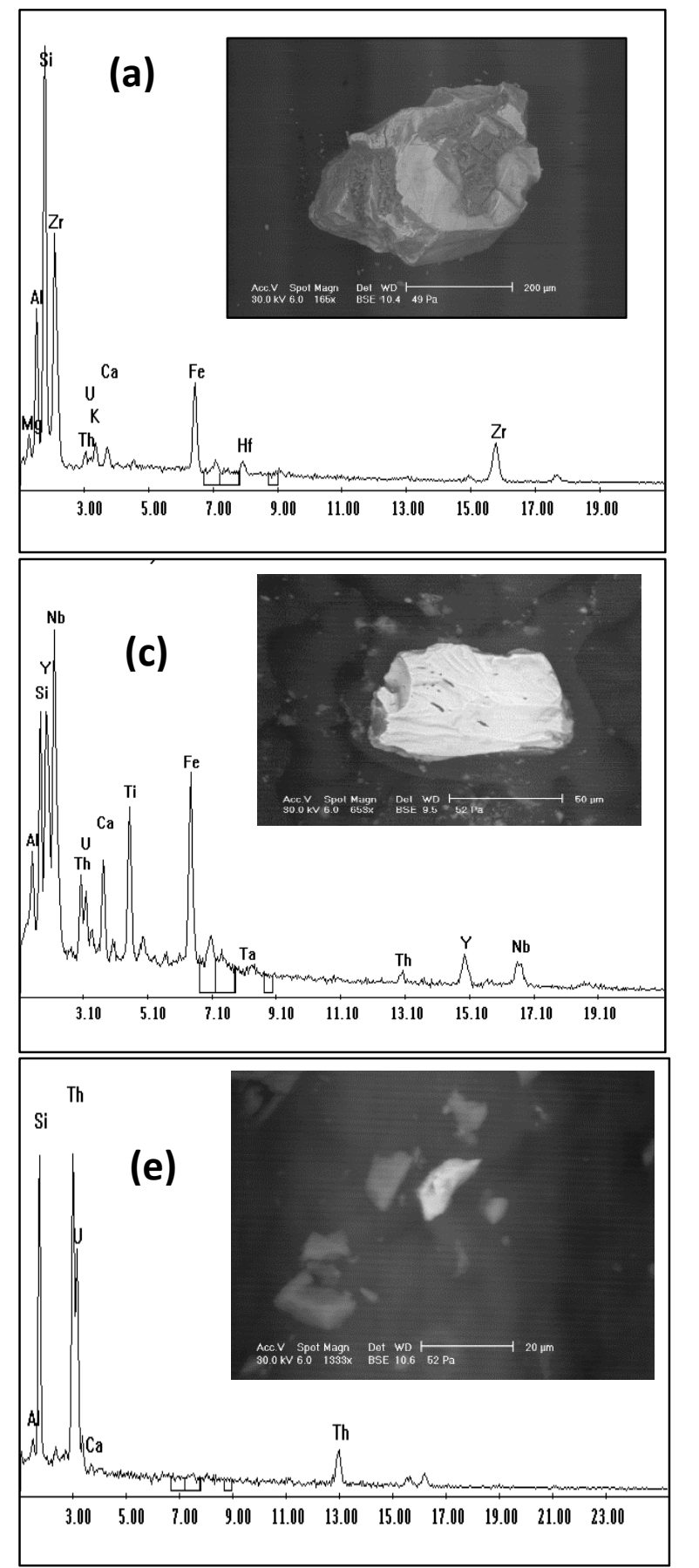
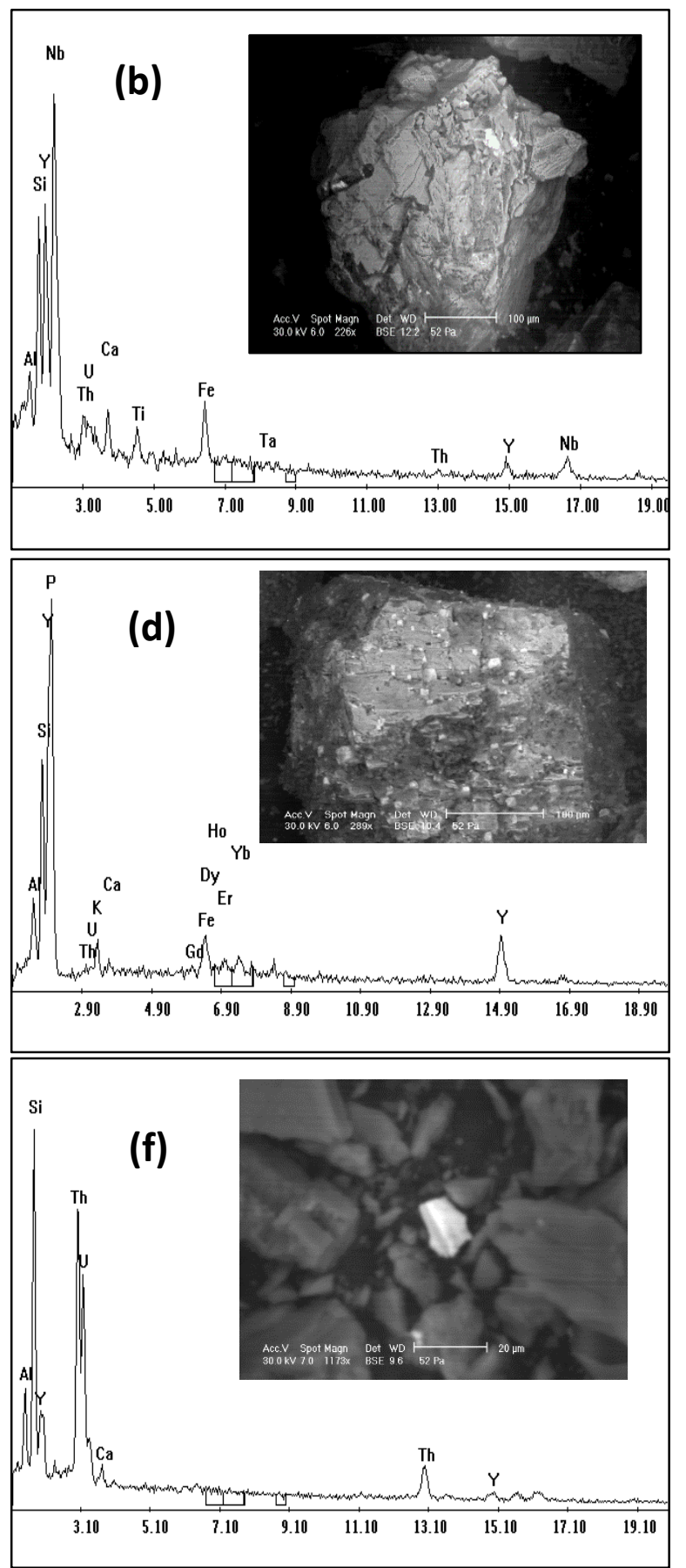

, (b) ESEM image and EDS spectrum of columbite(Fe), (c) ESEM image and EDS analysis of pyrochlore, (d) ESEM image and EDS spectrum of xenotime and $(\mathrm{e}, \mathrm{f})$ ESEM image and EDS analysis of uranothorite, studied radioactive pegmatites, Wadi Umm Balad area, NED, Egypt. 


\section{Conclusions}

Based on field and textural relationships, mineralogical and geochemical data, the following points can be concluded from the data presented in this work:

1- Field investigation revealed that the pegmatites of Wadi Umm Balad area frequently occur in close spatial association with aplites, quartz veins and dominantly felsic dikes, which cut granitic intrusions of monzogranite that emplaced into the DV and HS. The major mineral compositions of the pegmatites are not different from the host monzogranite, of which K-feldspar, quartz, plagioclase and micas are forming the major constituents.

2- The geochemistry of the monzogranite suggests that it is metaluminous and originated from alkalicalcic magma in post-orogenic environment and has characteristics of I-type granite. It is characterized by elevated contents of $\mathrm{SiO}_{2}$ and alkalis, low abundances of $\mathrm{MgO}, \mathrm{TiO}_{2}, \mathrm{CaO}$, and $\mathrm{P}_{2} \mathrm{O}_{5}$.

3- Radiometrical and mineralogical investigations of the radioactive pegmatites recorded in the study area show that they have high concentrations of $\mathrm{Zr}, \mathrm{Nb}, \mathrm{Y}$, Ta with different degrees of enrichments in $\mathrm{U}$ and $\mathrm{Th}$. This enrichment is attributed to presence of the radioactive minerals including zircon, columbite- $(\mathrm{Fe})$, pyrochlore, xenotime and uranothorite.

4- The higher enrichments of these trace elements and the strong positive correlations between U-Th, $\mathrm{U}-\mathrm{Nb}, \mathrm{U}-\mathrm{Zr}$ and $\mathrm{U}-\mathrm{Y}$ from the monzogranite samples toward the radioactive pegmatites, suggest normal differentiation from granite to highly evolved pegmatites. The overall data indicated that the studied pegmatites show affinity for NYF-family (Cerny and Ercit, 2005).

\section{References}

Abdel-Rahman A.M. and R. Doig, 1987. The Rb-Sr geochronological evolution of the Ras Gharib segment of the northern Nubian Shield. J Geol Soc London, 144: 577-586.

Abu Steet, A.A., 2002. Geology, geochemistry and radioactivity of Wadi Abu Maamal area, North Eastern Desert, Egypt, M. Sc. Thesis, Fac. Sci., Benha Univ., Cairo, Egypt, 174p.

Abu Steet, A.A., H.I. El Sundoly and A.A. Abdel Hamid, 2018: Rare elements distribution and mineralization potentiality of pegmatites in gabal Abu Samyuk granite, north Eastern Desert, Egyptian Journal of Geology, 62: 299-311.

Ali, B. A., 2007. Geochemistry of U-Th- REE bearing minerals, in radioactive pegmatite in Um SwassiDara area, north eastern desert, Egypt. AEC Jordan, 1: 197-209.

Asran, A.M.H., M.M. El Mansi, M.E. Ibrahim and I.M. Abdel Ghani, 2013. Pegmatites of Gabal El Urf, Central Eastern Desert, Egypt. The $7^{\text {th }}$ international conference of the geology of Africa, P-P IV-1 - IV-22, Assuit, Egypt.

Beyth, M., R.I. Stern, R. Altherr and A. Kroner, 1994. The Late Precambrian Timna igneous complex, southern Israel: Evidence for comagmatic-type sanukitoid monzodiorite and alkali granite magma. Lithos, 31:103-124.

Briqueu, L., H. Bougault and J.I. Joron, 1984. Quantification of Nb, Ta, Ti and V anomalies in magmas associated with subduction zones: Petrogenetic implications, Earth Planet. Sci. Lett., 68: 297308.

Cerny, P. and T.S. Ercit, 2005. The classification of granitic pegmatites revisited. The Canadian mineralogist, 43(6): 2005-2026.

Chappel, B.W. and A.J.R. White, 1992. I- and S-type granites in the Lachlan Fold Symposium on the origin of granites and related rocks. Geological Society of America, Special Paper, 272: 1-26.

Dardier, A.M., 2006. Geology, petrology and radioactivity of the older granitoids and younger granites of Gabal El-Umrah area, central Eastern Desert, Egypt. Delta J. Sci., Tanta Univ., 30: 1-16

De La Roche, H., J. Leterrier, P. Grand Claude and M. Marchal, 1980. A classification of volcanic and plutonic rocks using $\mathrm{R}_{1}-\mathrm{R}_{2}$ diagrams and major element analyses - its relationships with current nomenclature. Chem. Geol., 29: 183-210.

El Sundoly, H.I., 2021. Impact of tectonic factors on the emplacement of the radioactive mineralized pegmatites of Wadi Abu Zawal area, North Eastern Desert, Egypt. Curr. Sci. Int., 10 (1): 178 199 
Faüre, G., 1986. The U, Th-Pb methods of dating. In: Principles of isotope geology (2nd Ed.). John Wiley \& Sons: 228- 308.

Flanagan, F.J., 1976. Descriptions and analyses of eight new USGS rock standards. USGS professional paper 840: 131- 183.

Frost, B.R., C.G. Barnes, W.J. Collins, R.J. Arculus, D.J. Ellis and C.D. Frost, 2001. A Geochemical Classification for Granitic Rocks. J. Petrol., 42: 2033-2048.

Hassan, M.A. and A.H. Hashad, 1990. Precambrian of Egypt. In: Said, R. (ed.). The geology of Egypt, Balkema, Rotterdam, 201 - 245.

Hine, R., I.S. Williams, B.W. Chappell and A.J.R. White, 1978. Contrasts between I- and S-type granitoids of the Kosciusko Batholith. Journal of the Geological Society of Australia, 25: 219-234

Maniar, P.D. and P.M. Piccoli, 1989. Tectonic discrimination of granitoids. Geol Soc Am Bull 101: 635-643.

Mohamed, F.H., M.A. Hassanen and M.H. Shalaby, 1994. Geochemistry of Wadi Hawashia granite complex, Northern Egyptian Shield. J. Afr. Earth Sci., 19: 61-74.

Nossair, L.M., 1987. Structural and radiometric studies of Gebel Gharib area, north Eastern Desert, Egypt. PhD. Thesis, Fac. Sci., Alex. Univ., 182.

Pearce, J.A., 1996. Sources and settings of granitic rocks. Episodes, 19:120-125.

Pearce, J.A., N.B.W. Harris, and A.G. Tindle, 1984. Trace element discrimination diagrams for the tectonic interpretation of granitic rocks. J. Petrol., 25: 959-983.

Ressetar, R. and J.R. Monrad, 1983. Chemical composition and tectonic setting of the Dokhan volcanic formation, Eastern Desert, Egypt. J. Afr. Earth. Sci., 1(2): 103 - 112.

Saleh, G.M., 2007. Rare metal-bearing pegmatites from the South Eastern Desert of Egypt: Geology, geochemical characteristics and petrogenesis. Chinease Journal of Geochemistry, 26 (1): 8-22

Shand, S.J., 1951. Eruptive rocks. John-Wiley, New York, 488.

Stern, R.J., 1981. Petrogenesis and tectonic setting of the Late Precambrian ensimatic volcanic rocks, Central Eastern Desert of Egypt. Precam. Res. 16: 196 - 230.

Stern, R.J. and D. Gottfried, 1986. Petrogenesis of a Late Precambrian (575-600Ma) bimodal Suite in northeast Africa. Contrib Mineral Petrol, 92: 492-501.

Streckeisen, A., 1976. To each plutonic rock its proper name. Earth Sci. Rev., 12: 1-33.

Wilde, S.A. and K. Youssef, 2002. A re-evaluation of the origin and setting of the Late Precambrian Hammamat Group based on SHRIMP-U-Pb dating of detrital zircons from Gebel Umm Tawat, North Eastern Desert, Egypt. J. Geol. Soc. Lond., 159: 595-604. 